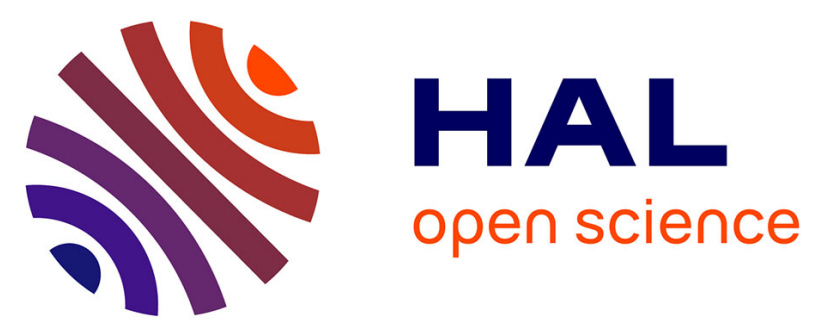

\title{
Blankaartia acuscutellaris (Walch, 1922) (Actinotrichida: Trombiculidae) collected from the great snipe Gallinago media (Latham, 1787) (Charadriformes: Scolopacidae) in Poland - new host and country record for chigger mite genus and species
}

\author{
Joanna Mąkol, Michal Korniluk
}

\section{To cite this version:}

Joanna Mąkol, Michal Korniluk. Blankaartia acuscutellaris (Walch, 1922) (Actinotrichida: Trombiculidae) collected from the great snipe Gallinago media (Latham, 1787) (Charadriformes: Scolopacidae) in Poland - new host and country record for chigger mite genus and species. Acarologia, 2017, 57 (3), pp.555-562. 10.24349/acarologia/20174180 . hal-01522052

\section{HAL Id: hal-01522052 \\ https://hal.science/hal-01522052}

Submitted on 12 May 2017

HAL is a multi-disciplinary open access archive for the deposit and dissemination of scientific research documents, whether they are published or not. The documents may come from teaching and research institutions in France or abroad, or from public or private research centers.
L'archive ouverte pluridisciplinaire HAL, est destinée au dépôt et à la diffusion de documents scientifiques de niveau recherche, publiés ou non, émanant des établissements d'enseignement et de recherche français ou étrangers, des laboratoires publics ou privés. 


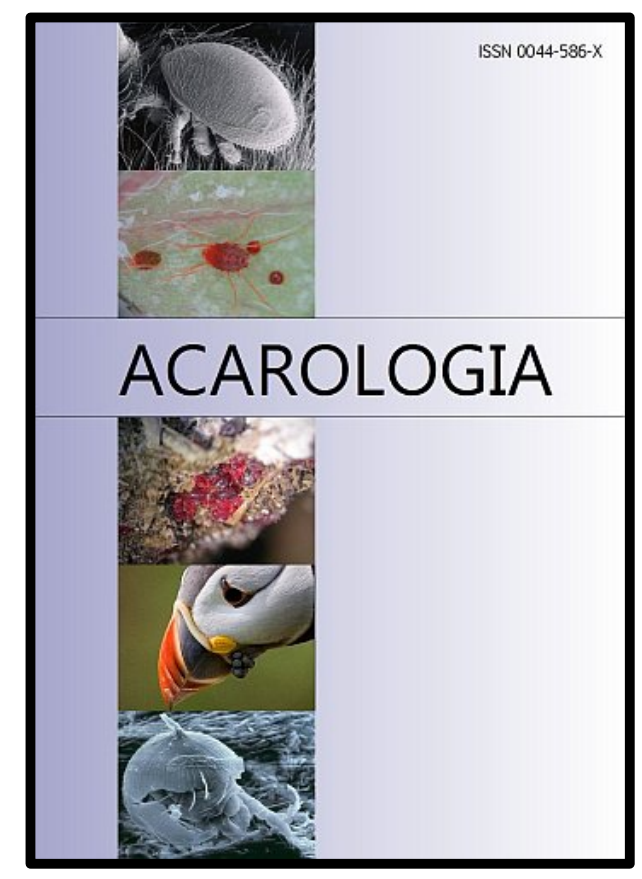

\section{ACAROLOGIA}

A quarterly journal of acarology, since 1959

Publishing on all aspects of the Acari

All information:

http://www1.montpellier.inra.fr/CBGP/acarologia/ acarologia@supagro.inra.fr

\section{OPEN ACCESS}

\section{Acarologia is proudly non-profit, with no page charges and free open access}

Please help us maintain this system by encouraging your institutes to subscribe to the print version of the journal and by sending us your high quality research on the Acari.

Subscriptions: Year 2017 (Volume 57): $380 €$ http://www1.montpellier.inra.fr/CBGP/acarologia/subscribe.php

Previous volumes (2010-2015): $250 € /$ year (4 issues)

Acarologia, CBGP, CS 30016, 34988 MONTFERRIER-sur-LEZ Cedex, France

The digitalization of Acarologia papers prior to 2000 was supported by Agropolis Fondation under the reference ID 1500-024 through the « Investissements d'avenir » programme

(Labex Agro: ANR-10-LABX-0001-01)
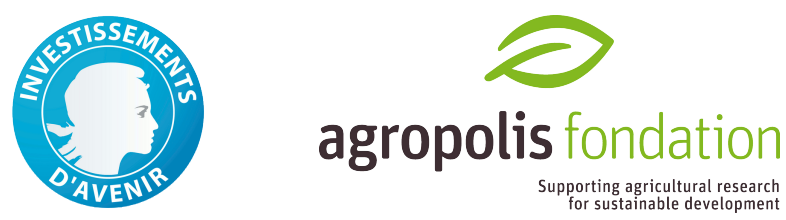

Acarologia is under free license and distributed under the terms of the

Creative Commons-BY-NC-ND which permits unrestricted non-commercial use, distribution, and reproduction in any medium, provided the original author and source are credited. 


\title{
Blankaartia acuscutellaris (Walch, 1922) (Actinotrichida: Trombiculidae) collected from the great snipe Gallinago media (Latham, 1787) (Charadriformes: Scolopacidae) in Poland - new host and country record for chigger mite genus and species
}

\author{
Joanna MAূKOL ${ }^{1 凶}$, Michał KORNILUK ${ }^{2}$ \\ (Received 06 October 2016; accepted 14 December 2016; published online 11 May 2017; edited by Farid FARAJI) \\ ${ }^{1}$ Department of Invertebrate Systematics and Ecology, Wrocław University of Environmental and Life Sciences, Kożuchowska 5b, 51-631 Wrocław, \\ Poland.joanna.makol@upwr.edu.pl (凶) \\ ${ }^{2}$ Museum and Institute of Zoology, Polish Academy of Sciences, Wilcza 64, 00-679 Warsaw, Poland. m.korniluk@miiz.waw.pl
}

\begin{abstract}
The parasitic chigger mite, Blankaartia acuscutellaris, collected from a female of Gallinago media is recorded from Poland for the first time. The locality, which constitutes the northernmost record of B. acuscutellaris in the Palaearctic, raises the question of the possibility of establishing a new population on the verges of the species' range distribution. Metric data for larvae, extending the knowledge of intra-specific variation, are provided.
\end{abstract}

KEYWORDS — Trombiculidae; Parasitengona; parasite; avian hosts; distribution; Europe

ZOOBANK — 270F2AE7-C3F4-4A92-B394-F7843C638626

\section{INTRODUCTION}

Trombiculid mite larvae, also known as chiggers, are common parasites of four-limbed vertebrates (Tetrapoda). Chiggers are considered to have a relatively wide host spectrum, due to their ecological and behavioural traits, though the knowledge is distorted by insufficient recognition of intraspecific variation and species boundaries. The chigger mite fauna, with its more than 3,000 morphologically distinguished species worldwide (Fernandes and Kulkarni 2003), reaches its highest diversity in the tropical and subtropical zones. Of around 260 chigger genera recognised worldwide, only few, for example Hypogastia Vercammen-
Grandjean, 1967, Neoschoengastia Ewing, 1929, Ornithogastia Vercammen-Grandjean, 1960, Toritrombicula Sasa, 1954 and Whartonacarus VercammenGrandjean, 1960, are known for their regular or exclusive associations with birds (Kalúz et al. 2016, Mertins et al. 2009, Takahashi et al. 2012).

Eighteen species of Trombiculidae, grouped in nine genera, have been hitherto recorded from Poland (Moniuszko and Makol 2014). For none of them the host spectrum is limited to birds, and for seven species only, i.e. Ascoschoengastia latyshevi (Schluger, 1955), Hirsutiella zachvatkini (Schluger, 1948), Leptotrombidium europaeum Daniel and Brelih, 1959, Miyatrombicula muris (Oudemans, 1910), Neotrombicula autumnalis (Shaw, 1790), Neotrombic- 


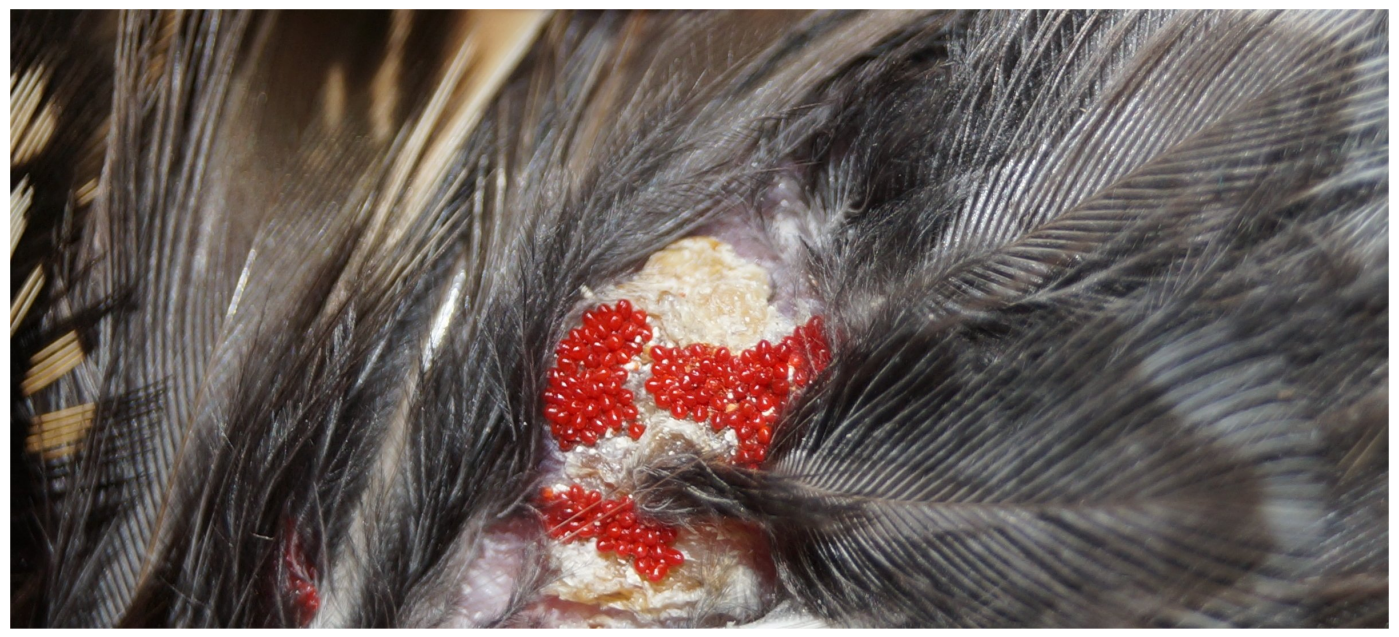

FIGURE 1: Blankaartia acuscutellaris (Walch, 1922). Larvae attached to the host's back.

ula inopinata (Oudemans, 1909) and Neotrombicula vernalis (Willmann, 1942), the host-parasite associations are shared between birds and mammals (Haitlinger 1987, Kudryashova 1998). The number of records, fairly incomplete and patchy, may be partly explained by the paucity of studies focused primarily on birds as chigger hosts.

In a survey of trombiculid mites infesting birds in Slovakia, four species, out of 16, were found to carry four species of Trombiculidae, i.e. Neotrombicula talmiensis (Schluger, 1955), N. autumnalis, L. europaeum and A. latyshevi (Daniel 1961), whereas 14 out of the 59 examined bird species in the Slovak and Polish Carpathians were recorded as hosts of $N$. vernalis and unidentified Trombiculidae (Literák et al. 2001). Literák et al. (2007) reported the presence of $A$. latyshevi in six species of birds out of the 20 examined. None of the bird-associated trombiculids listed by the above-mentioned authors, is regarded as an exclusive parasite of avian hosts and none has been recorded in shorebirds (Charadriformes) in Central Europe, including Poland.

Blankaartia Oudemans, 1911, with the type species Trombidium niloticum Trägårdh, 1905 is known for its complex taxonomic history documented and elucidated mainly by Fuller and Wharton (1951), Kudryashova (1983) and VercammenGrandjean (1973). The larvae, besides their affinity to small mammals, have been reported as frequent parasites of birds, including obligate mi- grants (Kudryashova 1998), and of reptiles (Taufflieb 1969). Of 29 species of Blankaartia described to date (Bassini-Silva et al. 2016), two, i.e. B. acuscutellaris and B. rageaui Taufflieb and Mouchet, 1959, have been recorded from Europe (Ripka and Stekolnikov 2006). The distribution of the former species encompasses Afrotropical, Palaearctic and Oriental Regions (Kudryashova 1983, Womersley 1948), whereas the few records of the latter species are limited to Equatorial Africa and Western Palaearctic (Kolebinova 1992).

Here we present the first record of a representative of Blankaartia, i.e. B. acuscutellaris, from Poland and, at the same time, the first record of its association with the great snipe Gallinago media. The finding alters the number of genera and species of Trombiculidae known from Poland to 10 and 19, respectively.

\section{MATERIALS AND METHODS}

Mite larvae were collected from a female of great snipe Gallinago media trapped in the environs of Odrynki village $\left(52^{\circ} 56^{\prime} \mathrm{N}, 23^{\circ} 38^{\prime} \mathrm{E}\right)$, Upper Narew River Valley (IBA PL048), Podlasie region, NE Poland, on the $4^{\text {th }}$ of May, 2015 by the junior author and his colleagues. Birds, in order to equip them with small GPS tracking devices, were captured with mist nets set on the leks. The larvae were removed with tweezers. 
Nine larvae, out of the 10 preserved in ethyl alcohol, were mounted on microscopic slides in Faure's liquid. Morphometric analysis was carried out in Nikon Eclipse E600 coupled with DIC, Nikon DsFi1 camera system and NIS Elements Br software. The stacked images (Figure 2) were produced using Combine ZP software. All measurements are given in micrometers. The morphological terminology and abbreviations follow Kudryashova (1998). The material is deposited in the Department of Invertebrate Systematics and Ecology, Wrocław University of Environmental and Life Sciences.

\section{RESULTS}

Approximately 150 larvae, bright red in colour (Figure 1), partly engorged and aggregated in three clusters, were relatively firmly attached to the skin of a great snipe. The mites were located in the middle part of the bird's back, above the rump, and close to the place where the tag was supposed to be attached. The skin lesions, partly healed, formed of thickened, exfoliated epidermis and devoid of plumage, were observed around and under the attachment places.

The following morphological character states were confirmed in the examined larvae: SIF $=7 \mathrm{BS}-$ N-3-3111.1000; $\mathrm{fP}_{\mathrm{p}}=\mathrm{B} / \mathrm{B} / \mathrm{NNB}$; $\mathrm{fSc}: \mathrm{PL}>\mathrm{AM}>$ $\mathrm{AL} ; \mathrm{fCx}=1.1 .1 ; \mathrm{fSt}=2.2 ; \mathrm{fD}=2 \mathrm{H}-6-6-6-4-2 ; \mathrm{NDV}$ $=44$. The characteristics of the larvae (see also Figure 2) fit the diagnosis of B. acuscutellaris (Walch 1922) and the data provided by Womersley (1948), Kudryashova (1983, 1998), Fernandes and Kulkarni (2003) and Ripka and Stekolnikov (2006). With respect to most meristic characters, the larvae fall within the range of variation provided by Ripka and Stekolnikov (2006) (for departing character states see Discussion). Metric data are provided in Table 1.

\section{DISCUSSION}

At present $B$. acuscutellaris is the only representative of the genus for which extensive information is available on morphological characteristics of heteromorphic, active instars. Deutonymphs experimentally reared from larvae were described by Radford
(1946); Womersley (1948) described deutonymphs and adults, whose identity with larvae was confirmed by experimental rearing accomplished by Jayewickreme and Niles $(1946,1947)$ and Radford (1946). The majority of metric data on the larvae examined in this study overlap with those provided by Womersley (1948), and/or Kudryashova (1983) and/or Ripka and Stekolnikov (2006) (Table 1). The differences in the length of tarsus III, length of legs I and II and index pedibus (IP), but also in the length of solenidion on tarsus I (13-15, present data), that is their lower values recorded for the larvae collected in Poland, unless verified by other evidence, should be attributed to host-driven intra-specific variation (Moniuszko et al. 2015) and/or likely to be influenced also by other environmental factors. The ultimate answer to the question of the background of this variation should be supported by molecular comparison of specimens from various localities, including the extreme ones, within the species distribution range. It is noteworthy, that the relatively wide range of IP values (803-1253, n $=13$ ) was observed also in the recently described Blankaartia shatrovi Bassini-Silva and Barros-Batesti, 2016 (Bassini-Silva et al. 2016).

The range of hosts known for larvae of B. acuscutellaris includes various species of mammals and birds (Kudryashova 1998), several of the latter known for long-distance migrations, but also reptiles (Taufflieb 1969). In several localities, including Hungary, larvae of B. acuscutellaris have been also reported to interact with humans and to cause cutaneous trombidiosis (Fernandes and Kulkarni 2003, Gater 1932, Ripka and Stekolnikov 2006, Walch 1927).

The distribution data on B. acuscutellaris, including the most recent and, at the same time - the northernmost record (Figure 3), may point to a gradual northward shifting of the species' distribution limits. The species was described from Sumatra (Walch 1922), then its distribution was extended to include the Eastern Palaearctic and Oriental Regions (Kudryashova 1998), Afrotropical Region (Taufflieb 1969, Taufflieb and Mouchet 1959) and single localities in Western Palaearctic (Ripka and Stekolnikov 2006, Varma 1964 and present data). 

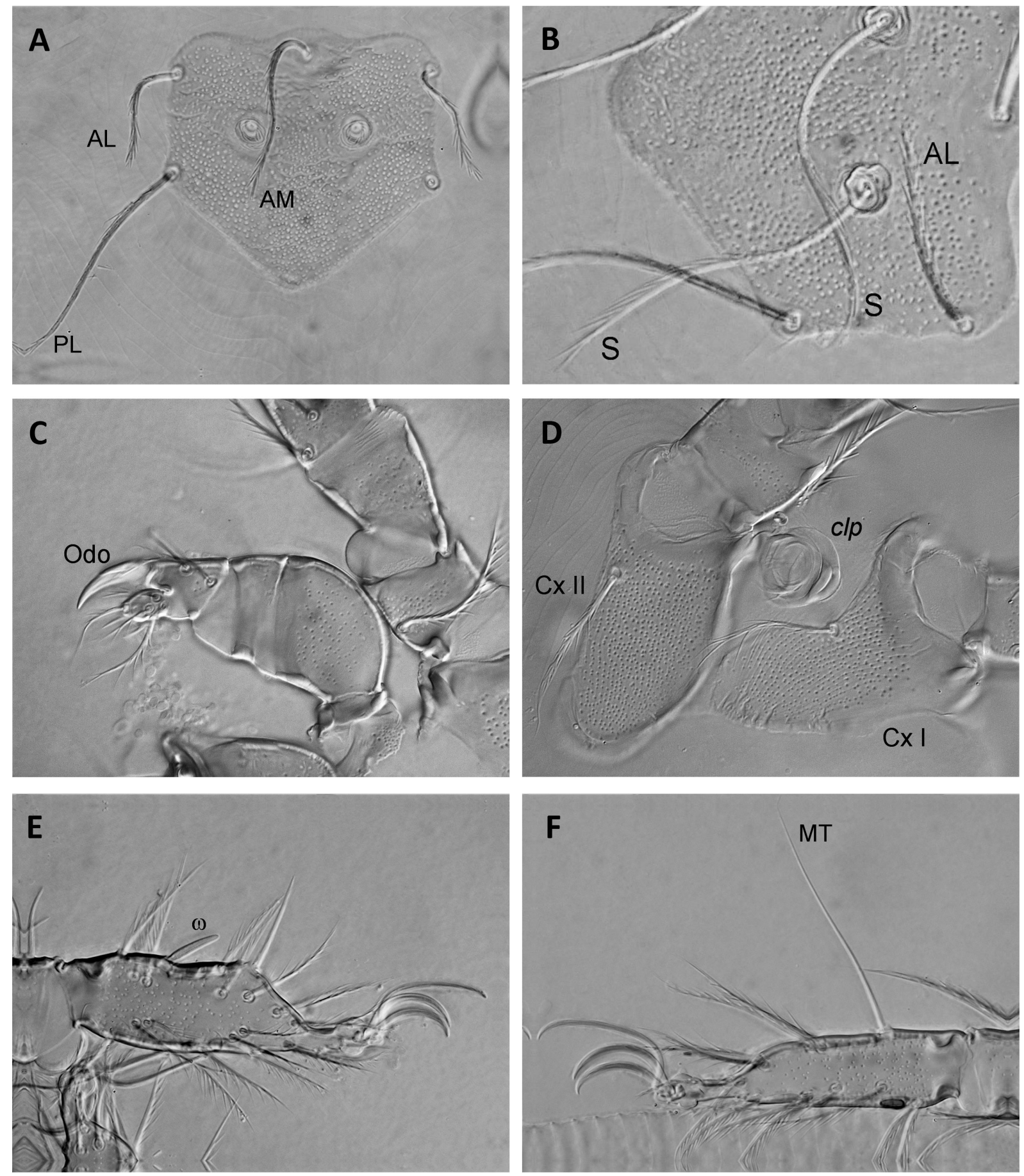

FIGURE 2: Blankaartia acuscutellaris (Walch, 1922), larva. A - scutum (setae S and one seta PL broken); B - scutum, S - sensilla, AL anterolateral seta on scutum; C - palp, Odo - odontus; D - coxa I-II, Cx I - coxa I, Cx II - coxa II, clp - Claparède's organ, note the linear layout of punctuations on coxal plates; E - tarsus I, $\omega$ - solenidion; F - tarsus III, MT - mastitarsala. 
TABLE 1: Standard measurements of Blankaartia acuscutellaris.

\begin{tabular}{ccccc}
\hline Womersley (1948)* & $\begin{array}{c}\text { Kudryashova (1983) } \\
\text { [Sri Lanka, Malaysia, } \\
\text { (ndter various } \\
\text { authors) }\end{array}$ & $\begin{array}{c}\text { Ripka and } \\
\text { Stekolnikov (2006) } \\
\text { [Hungary] }\end{array}$ & $\begin{array}{c}\text { present data } \\
\text { [Poland] }\end{array}$ \\
\hline AM & $50-56$ & $47-67$ & $59-70$ & $44-52$ \\
AL & $39-43$ & $31-45$ & $32-45$ & $30-37$ \\
AW & $70-84$ & $70-91$ & $82-87$ & $66-73$ \\
PL & $76-85$ & $54-88$ & $74-85$ & $61-69$ \\
PW & $76-87$ & $74-97$ & $87-90$ & $68-77$ \\
AP & $25-28$ & $22-33$ & $27-34$ & $26-31$ \\
S & 84 & $62-90$ & $77-85$ & $50-62$ \\
SB & $28-34$ & $28-41$ & $40-41$ & $27-30$ \\
ASB & $28-31$ & $26-35$ & $30-36$ & $24-32$ \\
PSB & $42-45$ & $37-56$ & $41-47$ & $39-45$ \\
P-PL & - & - & $31-35$ & $29-34$ \\
SD & $70-76$ & $68-86$ & $71-83$ & $65-76$ \\
Ta III (L) & - & - & $95-103$ & $76-84^{* *}$ \\
Ta III (W) & - & - & $21-23$ & $19-23$ \\
DS max & - & $51-93$ & $52-90$ & $63-80$ \\
leg I & - & $330-394$ & $355-387$ & $300-322$ \\
leg II & - & $299-376$ & $326-367$ & $267-294$ \\
leg III & - & $353-435$ & $380-421$ & $310-353$ \\
IP & - & $992-1123$ & $1060-1170$ & $878-944$ \\
\hline
\end{tabular}

*rounded to integers; **measured without claws

List of abbreviations (after Kudryashova 1998, with modifications); symbols apply to length, unless stated otherwise: scutum: AM - antero-medial seta, AL - anterolateral seta, AW - distance between bases of AL, PL - postero-lateral seta, PW - distance between bases of PL, AP - distance between bases of AL and PL (on one side of symmetry axis), S - sensillum, SB - distance between bases of S, ASB - distance between the level of sensilla (S) and anterior margin of scutum, PSB distance between the level of sensilla (S) and posterior margin of scutum, P-PL - distance between PL and posterior margin of scutum, SD - scutum (= ASB + PSB); Ta III (L) - length of tarsus III, Ta III (W) - width of tarsus III, DS max - dorsal idiosomal setae (maximum length), VS max - ventral idiosomal setae (maximum length), leg (...) - total length of leg (including coxae); IP (index pedibus, leg index) - total length of legs (I + II + III) on one side of symmetry axis. 


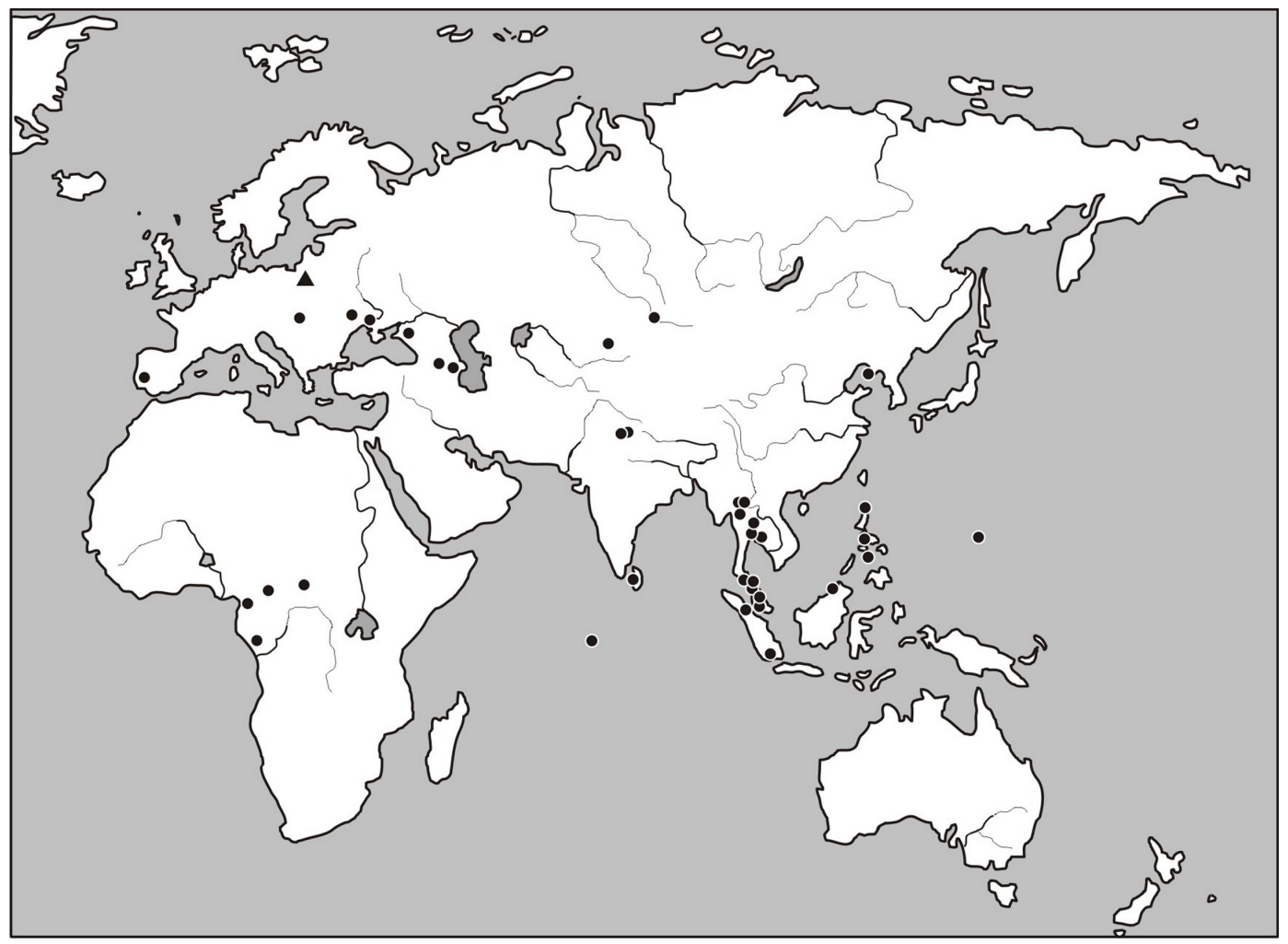

FIGURE 3: Distribution of Blankaartia acuscutellaris (Walch, 1922). Records after Kudryashova (1983, 1998), Fernandes and Kulkarni (2003) and Ripka and Stekolnikov (2006) indicated with dots; the new, northernmost record, indicated with triangle.

Floodplain meadows and fens, being typical habitats of the new host species, the great snipe, match the published information on the preferred habitats of B. acuscutellaris which comprise wet, temporarily inundated places, including river banks and swamps (Ripka and Stekolnikov 2006). This is of special importance in view of the further development of the mite, which involves predatory deutonymph and adult, as well as calyptostatic protonymph and tritonymph. The partial engorgement of the larvae of B. acuscutellaris collected from the great snipe Gallinago media indicates that the mites may have been attached to the host for a relatively short time; on the other hand, the healed scars observed on the host's skin, most likely denoting the places already left by other larvae, may suggest that at least some individuals may have managed to complete the parasitic phase. This supports the hypothesis of time-lagged parasitism already known in the Trombiculidae and explained by prolonged infestation in Hirsutiella zachvatkini (Moniuszko and
Makol 2016); however, it may also result from engorgement of larvae being interrupted by environmental factors which affect the host during migration. Nevertheless, the time required by larva for feeding, enabling it to transform into subsequent instar, does not seem to be tantamount to actual association with the host in trombiculids (Moniuszko and Mąol 2016).

Association with migrating hosts may facilitate the parasite's dispersal, possibly resulting in the area encompassing the hosts' wintering and breeding territories. Varma (1964), who collected ectoparasites from birds migrating from Africa to Europe, reported finding 23 fully engorged larvae of B. acuscutellaris on a single individual of the little bittern Ixobrychus minutus minutus (Pelecaniformes), trapped in April in Spain. Taufflieb and Mouchet (1959) collected larvae of B. acuscutellaris from the same host (sub)species, also in April, in Cameroon, an area located within the wintering grounds of the 
little bittern. The same mechanism may apply to other trombiculid species. For example, larvae of $N$. autumnalis were found on a single specimen of Ixobrychus minutus in April in Turkey (Cakiroglu et al. 2008). On the other hand, the rarity of reported cases may point to an accidental shifting rather than to a regular phenomenon. In no case should conclusions be drawn without considering the specificity of habitats preferred by the host species which, most likely, favour also successful transformation of larvae into subsequent instars. Undoubtedly, the trombiculid larvae, after transformation from pre-larval instar, find favourable conditions at their host's body, especially in view of decreasing humidity of the environment. The latter may also explain the higher infestation rate in the drier season, as reported by Dietsch (2005). Dietsch's (2005) studies confirm that, apart from the area in question, resident bird species constitute more suitable hosts for chiggers than migratory birds, which in turn may be due to the higher specialisation of residents and use of particular habitats.

It is noteworthy that the larvae of B. acuscutellaris were fully covered by feathers forming the great snipe's natural plumage. This may suggest that the mites may be overlooked by ornithologists during the standard ringing procedure, when no tag is being attached, nor parasite survey is being carried out. On the other hand, for the last four years, for ca 150 great snipes trapped in Poland and examined more carefully than during standard ringing, no skin parasites have been observed (Korniluk, unpublished).

Since no records of active post-larval forms are known from the northernmost localities of $B$. acuscutellaris, the question remains whether the larvae carried by migrating birds to Central Europe are able to complete their life cycle in the extreme localities. This kind of founder effect, resulting in a gradual northward extension of the distribution range, might be facilitated by the global warming as observed for various other invertebrate taxa.

\section{ACKNOWLEDGEMENTS}

We are grateful to Piotr Świętochowski and Tomasz Tumiel for their help in the field and during sample collection. Our thanks go to the anonymous Reviewers, whose comments helped to improve the manuscript.

\section{REFERENCES}

Bassini-Silva R., Jacinavicius F.C., Mendoza-Roldan J.A., Daemon E., Barros-Battesti D.E. 2016 - Description of Blankaartia shatrovi n. sp. (Acari: Trombiculidae) from Brazil - J. Med. Entomol., 1-9, doi:10.1093/jme/tjw149

Cakiroglu D., Pekmezci D., Meral Y., Gokalp G., Acici M. 2008 - Trombiculidae larvae (Neotrombicula autumnalis) infestation in a little bittern (Ixobrychus minutus) in Turkey — Parasitol. Res., 102: 1077-1079. doi:10.1007/s00436-008-0898-3

Daniel M. 1961 - The bionomics and developmental cycle of some chiggers (Acariformes, Trombiculidae) in the Slovak Carpathians - Česk. Parasitol., 8: 31-118.

Dietsch T.V. 2005 - Seasonal variation of infestation by ectoparasitic chigger mite larvae (Acarina: Trombiculidae) on resident and migratory birds in coffee agroecosystems of Chiapas, Mexico - J. Parasitol., 91: 1294-1303. doi:10.1645/GE-558R.1

Fernandes S.J., Kulkarni S.M. 2003 — Studies on the trombiculid mite fauna of India - Rec. Zool. Surv. India, Occasional Paper, 212: 1-539.

Fuller H.S., Wharton G.W. 1951 - The generic names Blankaartia Oudemans, 1911 and Trombiculoides Jacot, 1838 (Acari: Trombiculidae) - Psyche, 58: 85-88. doi:10.1155/1951/40161

Gater B.A.R. 1932 - Malayan trombidiid larvae, part 1. (Acarina: Trombidiidae) with descriptions of 17 new species - Parasitology, 24: 143-174.

Haitlinger R. 1987 — Dermanyssus alaudae (Schrank, 1781) i inne roztocze (Acari: Dermanyssidae, Macronyssidae, Haemogamasidae, Hirstionyssidae, Trombiculidae, Erythraeidae) zebrane z ptaków w Polsce Wiad. Parazytol., 33: 233-245.

Jayewickreme S.H., Niles W.J. 1946 - Successful feeding experiments with an adult trombiculid mite (Order Acarina) - Nature (London), 157: 878. doi:10.1038/157878a0

Jayewickreme S.H., Niles W.J. 1947 — Rearing of Trombicula acuscutellaris Walch — Nature (London), 160: 578.

Kalúz S., Hung N.M., Capek M., Literák I. 2016 Two new species and new records of chiggers (Acari: 
Leeuwenhoekiidae, Trombiculidae) from birds in Vietnam - Zootaxa, 4061: 483-503.

Kolebinova M.G. 1992 - Acariformes, Trombidioidea, Trombiculidae, Leeuwenhoekiidae - Fauna of Bulgaria, vol. 21. Aed. Acad. Sci. Bulg., Sofia, 1-172 [in Bulgarian].

Kudryashova N.I. 1983 - Revision of the genus Blankaartia (Acariformes, Trombiculidae) of the fauna of USSR - Sb. Trud. Zool. Muz. MGU, 20: 144-165 [in Russian].

Kudryashova N.I. 1998 - Chigger mites (Acariformes, Trombiculidae) of East Palaearctics - KMK Scientific Press, Moscow [in Russian].

Literák I., Honza M., Pinowska B., Haman A. 2001 - Larvae of trombiculid mites (Acarina: Trombiculidae) in wild birds in the Slovak and Polish Carpathians - Acta Vet. Brno, 70: 479-483. doi:10.2754/avb200170040479

Literák I., Kocianova E., Dusbábek F., Martinu J., Podzemny P., Sychra O. 2007 - Winter infestation of wild birds by ticks and chiggers (Acari: Ixodidae, Trombiculidae) in the Czech Republic - Parasitol. Res., 101: 1709-1711. doi:10.1007/s00436-007-0702-9

Mertins J.W., Hanson B.A., Corn J.L. 2009 - Whartonacarus floridensis sp. nov. (Acari: Trombiculidae), with a taxonomic review and the first record of Whartonacarus chiggers in the continental United States - J. Med. Entomol., 46: 1260-1268. doi:10.1603/033.046.0603

Moniuszko H., Mąkol J. 2014 - Chigger mites (Actinotrichida: Parasitengona, Trombiculidae) of Poland. An updated distribution and hosts - Ann. Parasitol., 60: 103-117.

Moniuszko H., Mąkol J. 2016 - Host-parasite association in trombiculid mites (Actinotrichida: Trombiculidae) of temperate zone - the case of Hirsutiella zachvatkini (Schluger, 1948); are we dealing with prolonged contact with the host? - Parasites \& Vectors, 9: 61, 1-9.

Moniuszko H., Zaleśny G., Mąkol J. 2015 - Hostassociated differences in morphometric traits of parasitic larvae Hirsutiella zachvatkini (Actinotrichida: Trombiculidae) - Exp. Appl. Acarol., 67: 123-133. doi:10.1007/s10493-015-9925-0

Radford C.D. 1946 - Larval and nymphal mites (Acarina: Trombiculidae) from Ceylon and the Maldive Islands — Parasitology, 37: 46-54.
Ripka G., Stekolnikov A.A. 2006 - First finding of the chigger mite Blankaartia acuscutellaris (Acari, Trombiculidae) on a human host in Europe - Belg. J. Entomol., 8: 147-151.

Takahashi M., Misumi H., Takahashi Y. 2012 - Toritrombicula lerdthusneei (Acari, Trombiculidae): a new species of chigger mite collected by Suzuki's method from Iriomotejima Island, Okinawa, Japan, with host and distribution records of the genus Toritrombicula Sasa, 1954 - Bull. Nat. Mus. Nat. Sci., ser. A, 38: 53-64.

Taufflieb R. 1969 - Blankaartia acuscutellaris (Acarina, Trombiculidae) et son extension au continent Africain - Acarologia, 11: 284-89.

Taufflieb R., Mouchet J. 1959 — Revue des Trombiculidae $\mathrm{du}$ Cameroun et description de huit especes et sousespeces nouvelles - Acarologia, 1: 228-45.

Varma M.G.R. 1964 - Mites (family Trombiculidae) parasitizing birds migrating from Africa to Europe - Bull. World Health Organ., 31: 411-416.

Vercammen-Grandjean P.H. 1973 - Taxonomie des Neotrombidiidae et épilogue naturel du problème Blankaartia nilotica (Trägårdh, 1905) (Trombidioidea) Acarologia, 15: 115-120.

Walch E. 1922 - Over Trombicula deliensis n. sp. vermoedelijke overbrengster der pseudo typhus, en andere Trombiculae van Deli (eerste mededeeling) - Geneesk. Tijd. Ned.-Ind., 62: 530-588.

Walch E. 1927 - Nederlandsch-Indische Trombiculae en verwante mijten, (derde mededeeling). Soorten uit de Lampongsche Districten en de Omgeving van Makassar - Geneesk. Tijd. Ned.-Ind., 67: 922-933.

Womersley H. 1948 - The genus Tragardhula Berlese, 1912 — Trans. R. Soc. S. Austr., 72: 83-90.

\section{COPYRIGHT}

$(\mathrm{cc}$ EY-No-ND Mąol J. and Korniluk M. Acarologia is under free license. This open-access article is distributed under the terms of the Creative Commons-BY-NC-ND which permits unrestricted non-commercial use, distribution, and reproduction in any medium, provided the original author and source are credited. 